\title{
Procedimentos terapêuticos em caso grave de papilomatose bovina
}

Maria do Carmo Sales da Silva, Alexandra Melo Oliveira, Karla Campos Malta", Igor Mariz Dantas, José Ferreira Neto, Antônio Carlos das Chagas e Souza Júnior, Ricardo Barbosa de Lucena, Sara Vilar Dantas Simões

Clínica de Grandes Animais, Hospital Veterinário, Centro de Ciências Agrárias, Universidade Federal da Paraíba (UFPB), Areia, PB, Brasil

*Autor correspondente

e-mail: karla@cca.ufpb.br

\section{Resumo}

A papilomatose é uma enfermidade infectocontagiosa crônica, causada por um grupo de vírus pertencentes à família Papillomaviridae, que apresenta tropismo pelo tecido epitelial escamoso e mucoso. Após penetrarem na pele, os papilomavírus infectam as células basais da epiderme, estimulando de forma expressiva a mitose das mesmas, resultando em acantose e hiperceratose. Os vírus infectam mais frequentemente animais com idade inferior a dois anos e ocasionam o desenvolvimento de tumores na pele e mucosas. Geralmente a enfermidade tem caráter autolimitante devido à formação de imunidade celular, porém alguns casos são de difícil resolução e a perpetuação de animais enfermos no rebanho pode favorecer a disseminação do agente e contaminação de outros animais. Em casos em que os papilomas ocorrem em grandes extensões do corpo, recomenda-se a utilização de tratamentos sistêmicos como a autohemoterapia, utilização de clorobutanol, diaceturato de diaminazina ou a vacina autógena, podendo-se ainda fazer a associação de vários tratamentos. 0 objetivo desse trabalho é relatar o tratamento de um caso grave de papilomatose bovina que acometeu novilha da raça Holandesa, com 2 anos e seis meses de idade, atendida no Hospital Veterinário da UFPB. $\mathrm{O}$ animal inicialmente apresentou verrugas na orelha esquerda que se disseminaram pelo corpo em aproximadamente 5 meses. A presença de lesões pedunculadas, do tipo "couve flor" e planas, em extensas regiões da face, pescoço e úbere levaram à suspeita de papilomatose. Na análise histopatológica das lesões foram visualizadas na epiderme projeções digitiformes exofíticas, corpúsculos de inclusão anfofílicos intracitoplasmáticos e marcada hiperceratose, sendo concluído o diagnóstico de papilomatose. Diante da gravidade do caso, optou-se pela associação de tratamentos sistêmicos. 0 diaceturato de diaminazeno foi utilizad o na dose de $3,5 \mathrm{mg} \backslash \mathrm{kg}$, com intervalo de sete dias em um total de quatro aplicações. A vacina autógena foi preparada e utilizou-se $10 \mathrm{ml}$ por via intramuscular a cada 7 dias, em um total de três aplicações. Nessa 
ocasião fez-se uso do levamisole como imunomodulador $(2 \mathrm{mg} / \mathrm{kg}$ ). Observou-se marcada redução nos papilomas, sendo realizada fácil remoção manual dos que não caíram espontaneamente. Pequenas lesões planas persistiram na face e barbela. No momento da alta prescreveu-se clorobutanol na dose de $12,5 \mathrm{mg} /$ $\mathrm{kg}(1 \mathrm{ml}$ de verrutrat $/ 20 \mathrm{~kg}$ ), duas aplicações, com intervalo de 10 dias. Em contato posterior, o proprietário relatou que houve melhora dos sintomas após a alta, porém algumas pequenas lesões planas persistiram. Pode-se concluir que o tratamento foi eficiente ao se considerar a condição inicial do animal. 